\title{
(2) OPEN ACCESS \\ Randomised trial of epinephrine dose and flush volume in term newborn lambs
}

\author{
Deepika Sankaran 지, ${ }^{1}$ Praveen K Chandrasekharan, ${ }^{2}$ Sylvia F Gugino, ${ }^{2}$ \\ Carmon Koenigsknecht, ${ }^{2}$ Justin Helman, ${ }^{2}$ Jayasree Nair, ${ }^{2}$ Bobby Mathew, ${ }^{2}$ \\ Munmun Rawat, ${ }^{2}$ Payam Vali, ${ }^{1}$ Lori Nielsen, ${ }^{2}$ Daniel J Tancredi, ${ }_{1}$ \\ Satyan Lakshminrusimha
}

- Additional material is published online only. To view, please visit the journal online (http://dx.doi.org/10.1136/ fetalneonatal-2020-321034).

'Department of Pediatrics, University of California Davis, Sacramento, California, USA ${ }^{2}$ Department of Pediatrics, University at Buffalo Jacobs School of Medicine and

Biomedical Sciences, Buffalo, New York, USA

\section{Correspondence to} Dr Deepika Sankaran, Pediatrics, University of California Davis, Sacramento, CA 95817, USA; dsankaran@ucdavis.edu

Received 25 October 2020 Revised 31 January 2021 Accepted 21 February 2021

Check for updates

(C) Author(s) (or their employer(s)) 2021. Re-use permitted under CC BY-NC. No commercial re-use. See rights and permissions. Published by BMJ.

To cite: Sankaran $D_{\text {, }}$ Chandrasekharan PK, Gugino SF, et al. Arch Dis Child Fetal Neonatal Ed Epub ahead of print: [please include Day Month Year]. doi:10.1136/ archdischild-2020-321034

\section{ABSTRACT \\ Objectives Neonatal resuscitation guidelines recommend $0.5-1 \mathrm{~mL}$ saline flush following $0.01-0.03 \mathrm{mg} / \mathrm{kg}$ of epinephrine via low umbilical venous catheter for persistent bradycardia despite effective positive pressure ventilation (PPV) and chest compressions (CC). We evaluated the effects of $1 \mathrm{~mL}$ vs $3 \mathrm{~mL} / \mathrm{kg}$ flush volumes and $0.01 \mathrm{vs} 0.03 \mathrm{mg} / \mathrm{kg}$ doses on return of spontaneous circulation (ROSC) and epinephrine pharmacokinetics in lambs with cardiac arrest.}

Design Forty term lambs in cardiac arrest were randomised to receive 0.01 or $0.03 \mathrm{mg} / \mathrm{kg}$ epinephrine followed by $1 \mathrm{~mL}$ or $3 \mathrm{~mL} / \mathrm{kg}$ flush after effective PPV and CC. Epinephrine (with $1 \mathrm{~mL}$ flush) was repeated every 3 min until ROSC or until 20 min. Haemodynamics, blood gases and plasma epinephrine concentrations were monitored.

Results Ten lambs had ROSC before epinephrine administration and 2 died during instrumentation. Among 28 lambs that received epinephrine, 2/6 in $0.01 \mathrm{mg} / \mathrm{kg}-1 \mathrm{~mL}$ flush, $3 / 6$ in $0.01 \mathrm{mg} / \mathrm{kg}-3 \mathrm{~mL} / \mathrm{kg}$ flush, $5 / 7$ in $0.03 \mathrm{mg} / \mathrm{kg}-1 \mathrm{~mL}$ flush and $9 / 9$ in $0.03 \mathrm{mg} / \mathrm{kg}-3$ $\mathrm{mL} / \mathrm{kg}$ flush achieved ROSC ( $p=0.02)$. ROSC was five times faster with $0.03 \mathrm{mg} / \mathrm{kg}$ epinephrine compared with $0.01 \mathrm{mg} / \mathrm{kg}$ (adjusted HR ( $95 \% \mathrm{Cl}) 5.08$ (1.7 to 15.25)) and three times faster with $3 \mathrm{~mL} / \mathrm{kg}$ flush compared with $1 \mathrm{~mL}$ flush (3.5 (1.27 to 9.71)). Plasma epinephrine concentrations were higher with $0.01 \mathrm{mg} / \mathrm{kg}-3 \mathrm{~mL} / \mathrm{kg}$ flush (adjusted geometric mean ratio 6.0 (1.4 to 25.7)), $0.03 \mathrm{mg} / \mathrm{kg}-1 \mathrm{~mL}$ flush (11.3 (2.1 to 60.3)) and $0.03 \mathrm{mg} /$ $\mathrm{kg}-3 \mathrm{~mL} / \mathrm{kg}$ flush (11.0 (2.2 to 55.3)) compared with $0.01 \mathrm{mg} / \mathrm{kg}-1 \mathrm{~mL}$ flush.

Conclusions $0.03 \mathrm{mg} / \mathrm{kg}$ epinephrine dose with $3 \mathrm{~mL} /$ $\mathrm{kg}$ flush volume is associated with the highest ROSC rate, increases peak plasma epinephrine concentrations and hastens time to ROSC. Clinical trials evaluating optimal epinephrine dose and flush volume are warranted.

\section{INTRODUCTION}

Currently, epinephrine is the only medication recommended in neonatal resuscitation ${ }^{1}$ and is indicated if the heart rate remains below 60 beats per minute (bpm) despite effective positive pressure ventilation (PPV) with $100 \% \mathrm{O}_{2}$ and chest compressions (CC). ${ }^{23}$ Time to return of spontaneous circulation (ROSC) is an important prognostic indicator of outcome. ${ }^{4}$ ROSC could potentially be expedited by delivering an effective dose of epinephrine by

\section{What is already known on this topic?}

- Neonatal resuscitation guidelines recommend epinephrine at a dose of $0.01-0.03 \mathrm{mg} / \mathrm{kg}$ via low umbilical venous catheter for persistent bradycardia despite positive pressure ventilation and chest compressions.

- The recommended flush volume following epinephrine administration is $0.5-1 \mathrm{~mL}$.

\section{What this study adds?}

First direct comparison of 0.01 and $0.03 \mathrm{mg} / \mathrm{kg}$ epinephrine via low umbilical venous catheter with different flush volumes in a transitioning perinatal model of cardiac arrest.

- Use of $0.03 \mathrm{mg} / \mathrm{kg}$ epinephrine results in higher odds of successful resuscitation and earlier return of spontaneous circulation (ROSC).

- Larger flush volume $(3 \mathrm{~mL} / \mathrm{kg})$ hastens ROSC.

an optimal route with high bioavailability. A threefold difference between the lower $(0.01 \mathrm{mg} / \mathrm{kg})$ and upper $(0.03 \mathrm{mg} / \mathrm{kg})$ range of epinephrine doses with no clear recommendations on the optimal initial dose increases complexity and risk of error. ${ }^{5-7}$ A recent retrospective study has shown that an initial low umbilical venous catheter (UVC) dose of $0.01 \mathrm{mg} / \mathrm{kg}$ necessitated repeated and escalating doses of epinephrine to achieve ROSC, resulting in high cumulative epinephrine doses (up to $0.13 \mathrm{mg}$ / $\mathrm{kg}) .{ }^{8}$ We have, therefore, chosen to study the lower-range and higher-range dose of epinephrine as recommended by the Neonatal Resuscitation Programme (NRP).

Intravenous administration through a low UVC is the preferred route of epinephrine administration and is followed by a $0.5-1 \mathrm{~mL}$ normal saline flush. The current recommended flush volume only clears the epinephrine past the 5 Fr UVC. This flush might be adequate in the presence of spontaneous circulation. It remains unknown if this flush volume is adequate to propel epinephrine from the umbilical vein to the right atrium and general circulation during CC in the setting of cardiac arrest. Propelling epinephrine with a larger flush volume may enhance the bioavailability by maintaining patency of the ductus venosus, reduce the need for 
repeat doses and the cumulative dose of epinephrine required to achieve ROSC. ${ }^{9-12}$

Our objectives were to study the joint and separate effects of the experimental factors: epinephrine doses $(0.01 \mathrm{mg} / \mathrm{kg}$ vs $0.03 \mathrm{mg} / \mathrm{kg}$ ) and flush volumes (low flush $=1 \mathrm{~mL}$ vs high flush $=3 \mathrm{~mL} / \mathrm{kg}$ normal saline) on the incidence of ROSC in an ovine model of perinatal asphyxial cardiac arrest. Secondary outcomes included time to ROSC, cumulative dose of epinephrine required and plasma epinephrine concentrations.

\section{METHODS}

\section{Animal preparation}

Time-dated healthy pregnant ewes (142 days gestation; term $\approx 145$ days) were obtained from May Family Enterprises, Buffalo Mills, Pennsylvania, USA. ${ }^{13}$ Following an overnight fast, the ewes were medicated with intravenous diazepam and ketamine, intubated and ventilated with $21 \% \mathrm{O}_{2}$ and $2 \%$ isoflurane as previously described. ${ }^{14}$ Following a caesarean section, term fetal lambs were partially exteriorised and intubated with a $4.5 \mathrm{~mm}$ endotracheal tube that was occluded to prevent air entry. After injecting the incision sites with bupivacaine, catheters were inserted into the right carotid artery and jugular vein of the lamb. Flow probes (Transonics, Ithaca, New York, USA) were placed around the left carotid artery, left pulmonary artery and ductus arteriosus to measure blood flows. The blood flows and blood pressures were continuously recorded using BIOPAC systems (Goleta, California, USA).

Inclusion criteria: term time-dated newborn lambs.

Exclusion criteria: excessive blood loss and cardiac arrest during instrumentation.

\section{Randomisation and masking}

Lambs were randomised to four groups prior to delivery using opaque envelopes: (1) $0.03 \mathrm{mg} / \mathrm{kg}$ epinephrine followed by $1 \mathrm{~mL}$ saline flush, (2) $0.03 \mathrm{mg} / \mathrm{kg}$ epinephrine followed by $3 \mathrm{~mL} / \mathrm{kg}$ saline flush, (3) $0.01 \mathrm{mg} / \mathrm{kg}$ epinephrine followed by $1 \mathrm{~mL}$ saline flush and (4) $0.01 \mathrm{mg} / \mathrm{kg}$ epinephrine followed by $3 \mathrm{~mL} / \mathrm{kg}$ saline flush. The veterinarian pharmacist prepared the doses based on the lamb's weight and did not participate in the resuscitation.

\section{Cardiac arrest}

The umbilical cord was occluded until the lamb's heart rate was $0 \mathrm{bpm}$ and the carotid arterial pressure and flow waveforms were flat. The umbilical cord was then clamped and cut, and the lamb was delivered to a warmer. A single lumen 5 Fr UVC was placed in an umbilical vein and advanced to $2-3 \mathrm{~cm}$ below the skin surface. Three electrocardiogram leads were placed. Five minutes after cardiac arrest, PPV was initiated with $21 \% \mathrm{O}_{2}$ and pressures of $35 / 5 \mathrm{~cm} \mathrm{H}_{2} \mathrm{O}$ with 40 breaths/min using a T-piece resuscitator. One minute after onset of PPV, CC were provided at $3: 1$ (CC:PPV) ratio and inspired $\mathrm{O}_{2}$ was increased to $100 \%$.

\section{Resuscitation}

$\mathrm{CC}$ were provided by one of two resuscitators for all studies. The first dose of epinephrine $(0.01 \mathrm{mg} / \mathrm{kg}$ or $0.03 \mathrm{mg} / \mathrm{kg})$ was administered through the low UVC at $5 \mathrm{~min}$ after onset of resuscitation. ${ }^{815}$ This dose was followed by a normal saline flush of either $1 \mathrm{~mL}$ (low flush) or $3 \mathrm{~mL} / \mathrm{kg}$ (high flush), based on randomisation. ROSC was defined as sustained spontaneous heart rate of $>100 \mathrm{bpm}$ with a systolic blood pressure $>40 \mathrm{~mm} \mathrm{Hg}$. Epinephrine at the same dose was repeated every 3 min until ROSC. The flush volume for repeated epinephrine doses was kept constant at $1 \mathrm{~mL}$ to limit excess fluid burden. Ten lambs that achieved ROSC before epinephrine administration were classified as 'spontaneous ROSC'. If ROSC was not achieved with epinephrine (maximum four doses), PPV and CC were continued for a total of $20 \mathrm{~min}$. If ROSC was achieved, the lamb was observed for 2 hours and blood gases, blood pressures and haemodynamics were monitored. Euthanasia was then performed using intravenous pentobarbital (Fatal-Plus, Vortech Pharmaceuticals, Dearborn, Michigan, USA).

\section{Blood draws}

Arterial blood samples were drawn at baseline prior to delivery, at cardiac arrest, at onset of PPV and every min thereafter for 15 min during resuscitation for blood gas analysis and plasma epinephrine concentrations. Plasma samples were frozen at $-80^{\circ} \mathrm{C}$ until analysis for epinephrine concentrations by ELISA (Eagle Biosciences, New York, USA).

\begin{tabular}{|c|c|c|c|c|c|c|}
\hline Parameter & $\begin{array}{l}\text { Spontaneous ROSC } \\
(n=10)\end{array}$ & $\begin{array}{l}0.01 \mathrm{mg} / \mathrm{kg} \\
\text { epinephrine-low } \\
\text { flush }(\mathrm{n}=6)\end{array}$ & $\begin{array}{l}0.01 \mathrm{mg} / \mathrm{kg} \\
\text { epinephrine-high } \\
\text { flush }(\mathrm{n}=6)\end{array}$ & $\begin{array}{l}0.03 \mathrm{mg} / \mathrm{kg} \text { epinephrine- } \\
\text { low flush }(\mathrm{n}=7)\end{array}$ & $\begin{array}{l}0.03 \mathrm{mg} / \mathrm{kg} \\
\text { epinephrine-high } \\
\text { flush }(\mathrm{n}=9)\end{array}$ & $P$ value \\
\hline Weight $(\mathrm{kg})$ & $4.30(0.86)$ & $3.82(0.49)$ & $4.65(1.74)$ & $4.45(1.33)$ & $3.73(0.94)$ & 0.26 \\
\hline $\operatorname{Sex}(n)$ & 4 females $(40 \%)$ & 3 females $(50 \%)$ & 3 females $(50 \%)$ & 4 females $(57 \%)$ & 5 females $(56 \%)$ & 0.12 \\
\hline Gestational age (day) & $140.8(0.8)$ & $140.5(1.1)$ & $141(1.1)$ & $141.6(1.8)$ & $140.1(0.8)$ & 1.00 \\
\hline Multiplicity & $\begin{array}{l}4 \text { singleton, } 5 \text { twins and } \\
1 \text { triplet }\end{array}$ & 5 twins, 1 triplet & 4 singleton, 2 twins & $\begin{array}{l}1 \text { singleton, } 5 \text { twins and } \\
1 \text { triplet }\end{array}$ & $\begin{array}{l}3 \text { singleton, } 4 \text { twins and } \\
2 \text { triplets }\end{array}$ & 0.24 \\
\hline Time to cardiac arrest (min) & $15.3(7.2)$ & $13.8(5.8)$ & $13.9(3.5)$ & $14.7(3.6)$ & $11.4(2.0)$ & 0.22 \\
\hline ROSC achieved n (\%) & 10 & $2(33.3 \%)$ & $3(50 \%)$ & $5(71.4 \%)$ & $9(100 \%)$ & 0.02 \\
\hline $\begin{array}{l}\text { ROSC with first dose of epinephrine } \\
n(\%)\end{array}$ & N/A & $1(16.7 \%)$ & $2(33.3 \%)$ & $3(42.9 \%)$ & $8(88.9 \%)$ & 0.04 \\
\hline $\begin{array}{l}\text { Median cumulative epinephrine dose } \\
(\mathrm{mg} / \mathrm{kg})\end{array}$ & $\mathrm{N} / \mathrm{A}$ & $0.04(0.03-0.04)$ & $0.03(0.01-0.04)$ & $0.045(0.03-0.06)$ & $0.03(0.03-0.03)$ & 0.19 \\
\hline Median time to ROSC from PPV (s) & $210(150-290)$ & $698(375-1020)$ & $400(395-530)$ & $480(375-600)$ & $360(339-420)$ & 0.22 \\
\hline $\begin{array}{l}\text { Median time to ROSC from epinephrine } \\
\text { and flush (s) }\end{array}$ & N/A & $128(75-180)$ & $40(35-60)$ & $95(60-120)$ & $39(30-60)$ & 0.10 \\
\hline
\end{tabular}

Low flush $=1 \mathrm{~mL}$ flush $(\sim 0.25-0.27 \mathrm{~mL} / \mathrm{kg})$, high flush=3 mL $/ \mathrm{kg}(\approx 10-12 \mathrm{~mL})$ flush. P values for testing the null hypothesis that the four non-spontaneous ROSC study groups are equal, using Fisher's exact test for the categorical variables and Kruskal-Wallis test for the continuous variables.

Continuous variables are summarised as mean (SD) or as median (IQR).

N/A, not available; PPV, positive pressure ventilation; ROSC, return of spontaneous circulation. 
Table 2 Comparison of incidence of and time to achieve return of spontaneous circulation (ROSC), plasma epinephrine concentrations and cumulative doses of epinephrine among the study groups

\begin{tabular}{|c|c|c|c|c|}
\hline \multicolumn{5}{|l|}{ Incidence of ROSC } \\
\hline Compared groups & AOR & Lower $\mathrm{Cl}$ & Upper Cl & $P$ value \\
\hline $\begin{array}{l}0.03 \text { vs } 0.01 \mathrm{mg} / \mathrm{kg} \\
\text { epinephrine dose }\end{array}$ & 11.43 & 1.16 & 112.25 & $0.04^{*}$ \\
\hline High flush versus low flush & 4.35 & 0.45 & 42.32 & 0.12 \\
\hline \multicolumn{5}{|c|}{ Incidence of ROSC after first dose of epinephrine } \\
\hline & AOR & Lower $\mathrm{Cl}$ & Upper Cl & $P$ value \\
\hline $\begin{array}{l}0.03 \text { vs } 0.01 \mathrm{mg} / \mathrm{kg} \\
\text { epinephrine dose }\end{array}$ & 8.28 & 0.82 & 83.58 & 0.07 \\
\hline High flush versus low flush & 5.84 & 0.62 & 55 & 0.12 \\
\hline \multicolumn{5}{|c|}{ Time to achieve ROSC from start of ventilation } \\
\hline & AHR & Lower Cl & Upper Cl & $P$ value \\
\hline 0.03 vs $0.01 \mathrm{mg} / \mathrm{kg}$ dose & 5.08 & 1.7 & 15.25 & $0.005^{*}$ \\
\hline High flush versus low flush & 3.5 & 1.27 & 9.71 & $0.02^{*}$ \\
\hline \multicolumn{5}{|c|}{ Plasma epinephrine concentrations at $1 \mathrm{~min}$ after epinephrine and flush } \\
\hline Compared groups & AGMR & Lower $\mathrm{Cl}$ & Upper Cl & $P$ value \\
\hline $\begin{array}{l}0.01 \mathrm{mg} / \mathrm{kg} \text { dose: high flush } \\
\text { vs low flush }\end{array}$ & 6.05 & 1.43 & 25.7 & $0.02 *$ \\
\hline $\begin{array}{l}0.03 \mathrm{mg} / \mathrm{kg} \text { dose: high flush } \\
\text { vs low flush }\end{array}$ & 0.98 & 0.21 & 4.5 & 0.97 \\
\hline $\begin{array}{l}\text { Low flush: } 0.01 \mathrm{mg} / \mathrm{kg} \\
\text { vs } 0.03 \mathrm{mg} / \mathrm{kg} \text { dose of } \\
\text { epinephrine }\end{array}$ & 11.34 & 2.13 & 60.31 & $0.006^{*}$ \\
\hline $\begin{array}{l}\text { High flush: } 0.01 \mathrm{mg} / \mathrm{kg} \\
\text { vs } 0.03 \mathrm{mg} / \mathrm{kg} \text { dose of } \\
\text { epinephrine }\end{array}$ & 1.83 & 0.50 & 6.61 & 0.34 \\
\hline $\begin{array}{l}0.03 \mathrm{mg} / \mathrm{kg} \text {-high flush vs } \\
0.01 \mathrm{mg} / \mathrm{kg} \text {-low flush }\end{array}$ & 11.04 & 2.20 & 55.27 & $0.005^{*}$ \\
\hline $\begin{array}{l}0.03 \mathrm{mg} / \mathrm{kg} \text {-low flush vs } \\
0.01 \mathrm{mg} / \mathrm{kg} \text {-high flush }\end{array}$ & 1.81 & 0.48 & 7.31 & 0.35 \\
\hline $\begin{array}{l}\text { ROSC after first dose } \\
\text { of epinephrine vs no } \\
\text { ROSC after first dose of } \\
\text { epinephrine }\end{array}$ & 0.47 & 0.18 & 1.20 & 0.11 \\
\hline \multicolumn{5}{|l|}{ Cumulative dose of epinephrine } \\
\hline Compared groups & Effect size & Lower $\mathrm{Cl}$ & Upper Cl & $P$ value \\
\hline $\begin{array}{l}\text { High flush versus low flush } \\
\text { (AGMR) }\end{array}$ & 0.98 & 0.96 & 1.0005 & 0.06 \\
\hline $\begin{array}{l}0.03 \text { vs } 0.01 \mathrm{mg} / \mathrm{kg} \\
\text { epinephrine doses (AGMR) }\end{array}$ & 1.02 & 0.9993 & 1.03 & 0.06 \\
\hline \multicolumn{5}{|c|}{$\begin{array}{l}\text { Cumulative dose of epinephrine between lambs that achieved ROSC and those that did not } \\
\text { achieve ROSC }\end{array}$} \\
\hline $\begin{array}{l}\text { ROSC after epinephrine } \\
\text { doses versus no ROSC after } \\
\text { epinephrine doses mean } \\
\text { difference (Satterthwaite- } \\
\text { adjusted Student's t-test) }\end{array}$ & 0.02 & 0.0001 & 0.05 & $0.049^{*}$ \\
\hline \multicolumn{5}{|c|}{$\begin{array}{l}\text { Low flush }=1 \mathrm{~mL}(\sim 0.25-0.27 \mathrm{~mL} / \mathrm{kg}) \text {, high flush }=3 \mathrm{~mL} / \mathrm{kg} \approx 10-12 \mathrm{~mL} \text {. } \\
{ }^{*} \mathrm{P}<0.05 \text {. } \\
\text { AGMR, adjusted geometric mean ratio; AHR, adjusted HR; AOR, adjusted } O R ; R O S C \text {, return of } \\
\text { spontaneous circulation. }\end{array}$} \\
\hline
\end{tabular}

\section{Primary outcome}

The primary outcome measure was incidence of ROSC.

\section{Secondary outcomes}

The secondary outcome measures were time to achieve ROSC, the cumulative dose of epinephrine needed and the plasma epinephrine concentrations.

\section{Statistical analysis}

To estimate the effects of each of the two factors in our experiment (high flush vs low flush and high dose vs low dose), for each outcome we specified both a 'main-effects only' model and a 'saturated' model that added an interaction term and used the Akaike Information Criterion to select the better of the fitted models. ${ }^{16}$

We used linear regression for natural log-transformed plasma epinephrine concentrations at minute 6. To back-transform results for log-transformed plasma epinephrine, we applied the inverse natural log function to convert sample means and SD for log-transformed data to geometric means (GM) and geometric SDs (GSD), respectively, and to express adjusted mean differences as adjusted GM ratios. Logistic regression was used for binary outcomes and Cox proportional hazards regression for time to ROSC from ventilation, treating the event time as rightcensored at $30 \mathrm{~min}$ for those animals who did not achieve ROSC.

Longitudinally collected haemodynamic data were summarised for each animal and time period using medians and then analysed using mixed-effects models to account for within-animal correlation. For blood flows, mean changes from fetal baseline to postROSC time periods were compared among the five groups by specifying separate mixed-effects models for each outcome with random intercepts (to control for within-animal correlation) and with fixed effects for each of the two binary experimental factors (high vs low flush and 0.03 vs $0.01 \mathrm{mg} / \mathrm{kg}$ dose), a binary indicator for the spontaneous ROSC group, a three-level timepoint variable (baseline, $0-10 \mathrm{~min}$ post-ROSC and $20-120 \mathrm{~min}$ postROSC) and the interactions of timepoint with each of the three binary indicators, which permits estimating the effects of each experimental factors as adjusted 'within-factor mean differences in post-ROSC timepoint differences from baseline' (adjusted mean differences in differences) and also permit contrasting the spontaneous ROSC group to the ' $0.01 \mathrm{mg} / \mathrm{kg}$ dose-low flush' group.

Robust SEs were used for all regression-based inferences, to protect against mild departures from modelling assumptions. Unadjusted comparisons for descriptive statistics were performed using standard methods noted in the tables. SAS software V.9.4 (Raleigh, North Carolina, USA) was used for all analyses. Sample size was calculated for the primary outcome (online supplemental file).

\section{RESULTS}

Among 40 fetal lambs that were instrumented, two died during instrumentation. Asphyxial arrest was induced in 38 lambs by cord occlusion. Birth weight, gender, gestational age and multiplicity were not different between the study groups (table 1). Ten lambs that achieved ROSC prior to epinephrine administration (spontaneous ROSC) were not included in the analysis. The remaining 28 lambs received epinephrine and the rate of ROSC is shown in table 1 .

\section{Primary outcomes}

Among the nine lambs (100\%) that achieved ROSC in the 0.03 $\mathrm{mg} / \mathrm{kg}$ dose-high flush group, eight (89\%) did so with the first dose of epinephrine (table 1). The better fitting regression models for incidence and time to ROSC were the 'main effects only' models.

\section{Incidence of ROSC}

For a given dose of epinephrine (either 0.01 or $0.03 \mathrm{mg} / \mathrm{kg}$ ), use of high flush did not have a significant effect on odds of ROSC when compared with low flush (adjusted OR (AOR) 4.35 (95\% CI 0.45 to 42.32$)$ ), whereas for a given flush volume $(1 \mathrm{~mL}$ or $3 \mathrm{~mL} / \mathrm{kg}$ ), $0.03 \mathrm{mg} / \mathrm{kg}$ epinephrine resulted in an 11-fold higher odds of ROSC compared with $0.01 \mathrm{mg} / \mathrm{kg}$ (AOR 11.43 (1.16 to 


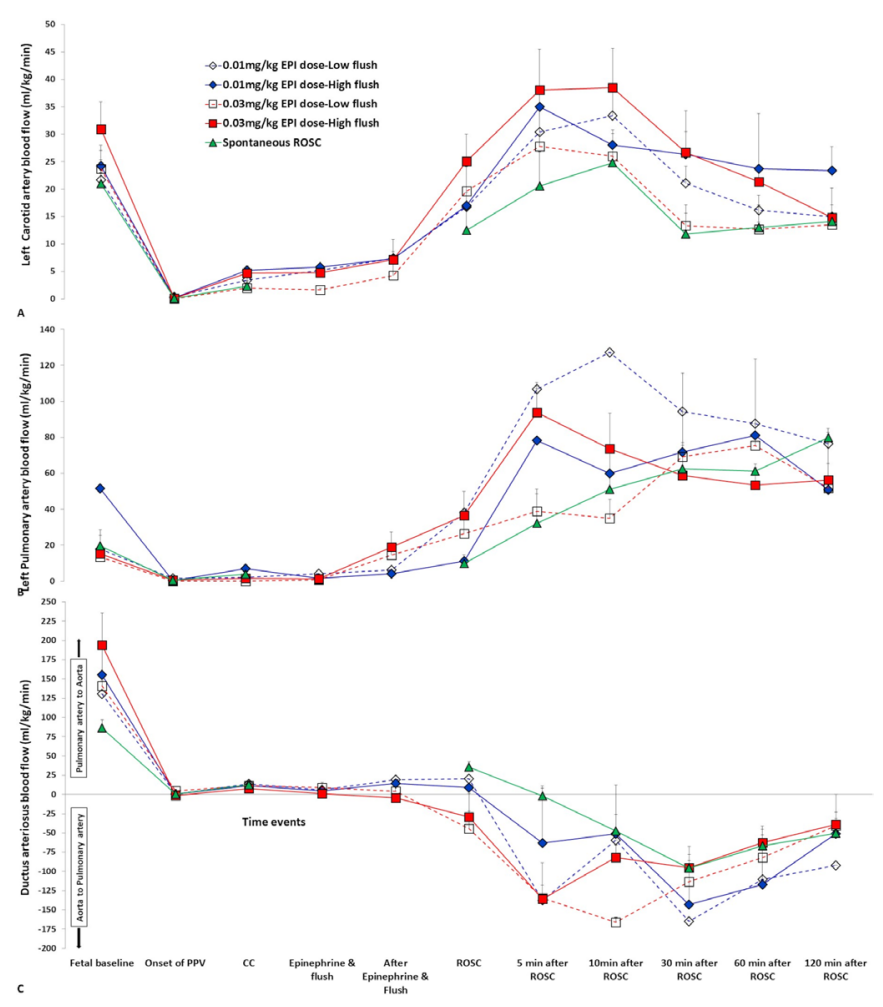

Figure 1 Invasive haemodynamics during resuscitation and after return of spontaneous circulation (ROSC) in the study groups. (A) Change in left carotid arterial blood flow. (B) Change in pulmonary arterial blood flow. (C) Change in ductal blood flow. Data presented as mean \pm SEM. EPI, epinephrine. CC, chest compressions; PPV, positive pressure ventilation.

112.25), $\mathrm{p}=0.04$,$) . The effect of using high flush versus low flush$ (AOR 5.84 (0.62 to 55$), \mathrm{p}=0.12$ ) and $0.03 \mathrm{mg} / \mathrm{kg}$ vs $0.01 \mathrm{mg} /$ $\mathrm{kg}$ epinephrine (AOR 8.28 (0.82 to 83.58), $\mathrm{p}=0.07$ ) were not different on the odds of ROSC with first dose of epinephrine.

\section{Secondary outcomes}

The time to achieve ROSC from ventilation was five times shorter with $0.03 \mathrm{mg} / \mathrm{kg}$ epinephrine dose compared with $0.01 \mathrm{mg} / \mathrm{kg}$ (AHR 5.08 (95\% CI 1.7 to 15.25$), \mathrm{p}=0.005)$ and was three times shorter with high flush compared with low flush (AHR 3.5 (1.27 to 9.71), $\mathrm{p}=0.02$ ) when adjusting for flush volume and dose, respectively (table 2 ).

The cumulative dose of epinephrine needed was not different among the four study groups (table 1). Cumulative epinephrine dose was similar with $0.03 \mathrm{mg} / \mathrm{kg}$ compared with $0.01 \mathrm{mg} / \mathrm{kg}$ epinephrine $(\mathrm{AGMR}=1.02$ (95\% CI 0.99 to 1.03$)$ ).

\section{Plasma epinephrine concentrations}

GM plasma epinephrine concentrations at $1 \mathrm{~min}$ after epinephrine administration (and $6 \mathrm{~min}$ after ventilation onset) were 6-fold higher with high flush compared with low flush when $0.01 \mathrm{mg} / \mathrm{kg}$ epinephrine was used (GM $\pm \mathrm{GSD}, 521.3 \pm 2.3$ vs $86.2 \pm 3.3 \mathrm{ng} / \mathrm{mL}$, AGMR 6.05 (95\% CI 1.43 to 25.7 ), $\mathrm{p}=0.02$ ), 11 -fold higher with $0.03 \mathrm{mg} / \mathrm{kg}$ epinephrine compared with $0.01 \mathrm{mg} / \mathrm{kg}$ when low flush was used (AGMR 11.34 (2.13 to $60.31), p<0.01$ ) and were 11 -fold higher with use of $0.03 \mathrm{mg} /$ $\mathrm{kg}$ epinephrine-high flush compared with use of $0.01 \mathrm{mg} / \mathrm{kg}$-low flush (AGMR 11.04 (2.20 to 55.27), p<0.01).
Haemodynamic parameters and gas exchange

There were no differences in left carotid, left pulmonary and ductus arteriosus flows during the study period (figure 1), and the mean blood pressures and heart rates following ROSC (figure 2). The arterial $\mathrm{pH}$ and plasma lactate concentrations at arrest and after ROSC were similar between the study groups (table 3).

\section{DISCUSSION}

Four million newborn infants experience perinatal asphyxia each year, accounting for an estimated 904000 deaths and 42 million disability-adjusted life years. ${ }^{17}$ Neonatal cardiac arrest and bradycardia in the delivery room contribute to this burden ${ }^{2}$ and rapid ROSC may improve outcomes. To our knowledge, this is the first comparison of two doses of UVC epinephrine within the range recommended by the American Academy of Pediatrics-NRP. In the current study, we demonstrate that $0.03 \mathrm{mg} / \mathrm{kg}$ of epinephrine is associated with earlier and higher incidence of ROSC and higher plasma epinephrine concentrations (with $1 \mathrm{~mL}$ flush) compared with the $0.01 \mathrm{mg} / \mathrm{kg}$ dose. Although a $0.03 \mathrm{mg} / \mathrm{kg}$ dose followed by high flush resulted in 100\% ROSC, the benefit appeared to be mostly due to the higher dose of epinephrine than the increased volume of flush. Time to achieve ROSC was faster with use of $0.03 \mathrm{mg} / \mathrm{kg}$ epinephrine compared with $0.01 \mathrm{mg} / \mathrm{kg}$ and $3 \mathrm{~mL} / \mathrm{kg}$ compared with $1 \mathrm{~mL}$ flush volume following the dose. We also demonstrate that administration of $0.03 \mathrm{mg} / \mathrm{kg}$ of epinephrine followed by a $3 \mathrm{~mL} / \mathrm{kg}$ flush increases the incidence and hastens ROSC without higher heart rates or blood pressures compared with $0.01 \mathrm{mg} / \mathrm{kg}$ dose.

The flush volume following UVC epinephrine of $0.5-1 \mathrm{~mL}$ per the current guidelines may clear the five Fr single lumen UVC (internal volume of $0.55 \mathrm{~mL}$ ) and deposit epinephrine in the umbilical vein. ${ }^{18}$ In the absence of umbilical blood flow (as in cardiac arrest), the inlet of the ductus venosus offers higher

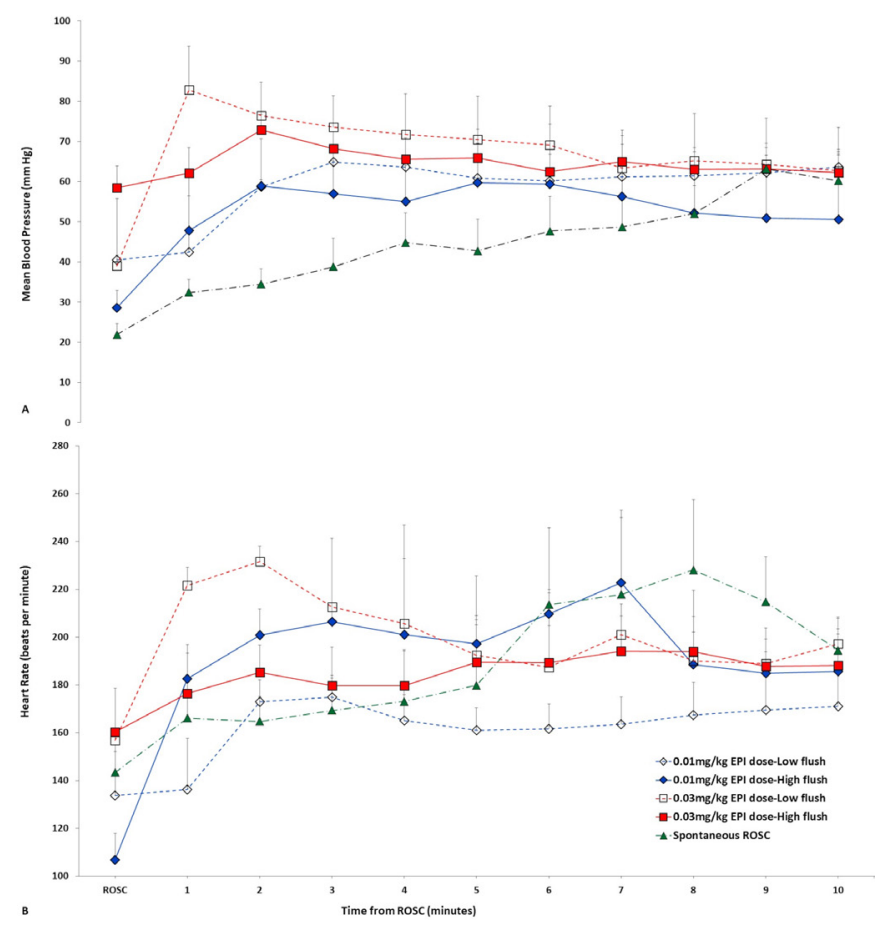

Figure 2 Mean blood pressures and heart rates after return of spontaneous circulation (ROSC). (A) Change in mean blood pressure after ROSC in the study groups. (B) Change in heart rates after ROSC in the study groups. Data presented as mean \pm SEM. EPI, epinephrine. 
Table 3 Preductal right carotid arterial blood gas parameters in the study groups

\begin{tabular}{|c|c|c|c|c|c|}
\hline Parameter & $\begin{array}{l}\text { Spontaneous ROSC } \\
(\mathrm{n}=10)\end{array}$ & $\begin{array}{l}0.01 \mathrm{mg} / \mathrm{kg} \\
\text { epinephrine-low flush } \\
(\mathrm{n}=6)\end{array}$ & $\begin{array}{l}0.01 \mathrm{mg} / \mathrm{kg} \\
\text { epinephrine-high flush } \\
(\mathrm{n}=6)\end{array}$ & $\begin{array}{l}0.03 \mathrm{mg} / \mathrm{kg} \\
\text { epinephrine-low flush } \\
(\mathrm{n}=7)\end{array}$ & $\begin{array}{l}0.03 \mathrm{mg} / \mathrm{kg} \\
\text { epinephrine-high flush } \\
(\mathrm{n}=9)\end{array}$ \\
\hline \multicolumn{6}{|c|}{ After arrest and prior to resuscitation } \\
\hline $\mathrm{pH}$ & $6.86(0.07)$ & $6.89(0.11)$ & $6.85(0.06)$ & $6.88(0.07)$ & $6.86(0.08)$ \\
\hline $\mathrm{PaCO}_{2}(\mathrm{~mm} \mathrm{Hg})$ & $137(16)$ & $113(6)$ & $124(22)$ & $142(16)$ & $129(24)$ \\
\hline $\mathrm{PaO}_{2}(\mathrm{~mm} \mathrm{Hg})$ & $6(4)$ & $7(4)$ & $13(7)$ & $6(3)$ & $8(4)$ \\
\hline Lactate (mmol/L) & $10.5(3.5)$ & $11.4(2.9)$ & $9.3(2.3)$ & $10.1(1.3)$ & $9.7(2.4)$ \\
\hline At ROSC & $\mathrm{n}=10$ & $\mathrm{n}=2$ & $n=2$ & $n=5$ & $n=9$ \\
\hline $\mathrm{pH}$ & $6.89(0.09)$ & $6.81(0.28)$ & $6.86(0.06)$ & $6.98(0.11)$ & $6.83(0.10)$ \\
\hline $\mathrm{PaCO}_{2}(\mathrm{~mm} \mathrm{Hg})$ & $103(14)$ & $78(18)$ & $81(31)$ & $75(24)$ & $97(33)$ \\
\hline $\mathrm{PaO}_{2}(\mathrm{~mm} \mathrm{Hg})$ & $34(10)$ & $40(2)$ & $89(110)$ & $290(232)$ & $89(85)$ \\
\hline $\mathrm{FiO}_{2}$ & $0.93(0.22)$ & $1(0)$ & $0.74(0.46)$ & $1(0)$ & $1(0)$ \\
\hline Lactate (mmol/L) & $12.6(3.6)$ & $16.8(4.5)$ & $9.4(2.8)$ & $12.4(2.2)$ & $11.0(2.9)$ \\
\hline 1 min after ROSC & $\mathrm{n}=8$ & $n=2$ & $\mathrm{n}=2$ & $n=5$ & $\mathrm{n}=9$ \\
\hline $\mathrm{pH}$ & $6.89(0.10)$ & $6.86(0.17)$ & $6.85(0.09)$ & $7.04(0.21)$ & $6.84(0.07)$ \\
\hline $\mathrm{PaCO}_{2}(\mathrm{~mm} \mathrm{Hg})$ & $105(21)$ & $61(12)$ & $87(31)$ & $66(41)$ & $105(32)$ \\
\hline $\mathrm{PaO}_{2}(\mathrm{~mm} \mathrm{Hg})$ & $46(47)$ & $132(65)$ & 145 (135) & $308(224)$ & $226(184)$ \\
\hline $\mathrm{FiO}_{2}$ & $0.55(0.33)$ & $0.61(0.56)$ & $0.67(0.41)$ & $0.94(0.09)$ & $0.62(0.39)$ \\
\hline Lactate (mmol/L) & $12(3.8)$ & $17.4(5)$ & $9.5(3.2)$ & $12.7(3)$ & $11.8(2.8)$ \\
\hline $5 \mathrm{~min}$ after ROSC & $\mathrm{n}=10$ & $\mathrm{n}=2$ & $\mathrm{n}=2$ & $n=5$ & $\mathrm{n}=9$ \\
\hline $\mathrm{pH}$ & $6.95(0.15)$ & $6.93(0.36)$ & $6.85(0.08)$ & $7.15(0.22)$ & $6.94(0.13)$ \\
\hline $\mathrm{PaCO}_{2}(\mathrm{~mm} \mathrm{Hg})$ & $88(31)$ & $55(21)$ & $85(21)$ & $53(40)$ & $83(47)$ \\
\hline $\mathrm{PaO}_{2}(\mathrm{~mm} \mathrm{Hg})$ & $69(55)$ & $91(61)$ & $97(69)$ & $202(140)$ & $98(62)$ \\
\hline $\mathrm{FiO}_{2}$ & $0.59(0.33)$ & $0.26(0.07)$ & $0.44(0.20)$ & $0.58(0.39)$ & $0.33(0.26)$ \\
\hline Lactate (mmol/L) & $11.7(4.2)$ & $16.2(5.4)$ & $9.5(3.3)$ & $11.8(2)$ & $10.9(2.8)$ \\
\hline $10 \mathrm{~min}$ after ROSC & $\mathrm{n}=10$ & $\mathrm{n}=2$ & $\mathrm{n}=2$ & $n=5$ & $\mathrm{n}=8$ \\
\hline $\mathrm{pH}$ & $7.11(0.16)$ & $7.01(0.33)$ & $7.06(0.04)$ & $7.20(0.20)$ & $7.10(0.19)$ \\
\hline $\mathrm{PaCO}_{2}(\mathrm{~mm} \mathrm{Hg})$ & $54(24)$ & $43(13)$ & $45(10)$ & $44(33)$ & $63(42)$ \\
\hline $\mathrm{PaO}_{2}(\mathrm{~mm} \mathrm{Hg})$ & $126(99)$ & $101(33)$ & $100(19)$ & $117(56)$ & $102(26)$ \\
\hline $\mathrm{FiO}_{2}$ & $0.49(0.31)$ & $0.26(0.64)$ & $0.30(0.13)$ & $0.45(0.35)$ & $0.33(0.25)$ \\
\hline Lactate (mmol/L) & $11.2(4.4)$ & $15.9(5.8)$ & $8.9(3.4)$ & $11.5(1.9)$ & $10.4(2.7)$ \\
\hline
\end{tabular}

Low flush $=1 \mathrm{~mL}$ flush $(\sim 0.25-0.27 \mathrm{~mL} / \mathrm{kg})$, high flush $=3 \mathrm{~mL} / \mathrm{kg}(\approx 10-12 \mathrm{~mL})$ flush.

The variables were not statistically differently distributed among the groups (Kruskal-Wallis).

Data are represented as mean (SD).

ROSC, return of spontaneous circulation.

resistance to flow. ${ }^{18}$ The terminal portion of the inferior vena cava and ductus venosus do not have valves and pressure from CC can potentially cause back-flow. Epinephrine increases portal venous resistance promoting distribution within the liver. Epinephrine delivery to the right atrium can potentially be enhanced by a quick flush with a mini-bolus to maintain patency of the ductus venosus and enhance delivery to the heart in the absence of spontaneous circulation. ${ }^{18}$

Recently, Songstad et al reported ROSC in 5/6 lambs with $0.05 \mathrm{mg}$ dose of jugular venous epinephrine followed by a $5 \mathrm{~mL}$ flush. ${ }^{19}$ The duration of asphyxia in their study was short along with a different approach which included $30 \mathrm{~s}$ of sustained inflation with $21 \% \mathrm{O}_{2}$ followed by PPV with $100 \% \mathrm{O}_{2}$ and uncoordinated CC. After $60 \mathrm{~s}$, a fixed dose of intravenous epinephrine $(0.05 \mathrm{mg}, \sim 0.01 \mathrm{mg} / \mathrm{kg})$ was administered through a jugular venous catheter followed by a $5 \mathrm{~mL}$ flush. In our study, the lambs were resuscitated $5 \mathrm{~min}$ after cardiac arrest. We adhered to the NRP guidelines and administered epinephrine after $4 \mathrm{~min}$ of CC to mimic clinical situations (to account for time to place a low UVC). The outcomes observed by Songstad et al were better ${ }^{19}$ compared with the ROSC outcomes with $0.01 \mathrm{mg} / \mathrm{kg} / \mathrm{dose}$ in our study possibly due to the shorter duration of asphyxia, jugular venous route and earlier administration of epinephrine with $5 \mathrm{~mL}$ flush.

We acknowledge several limitations in our study. Since randomisation was performed before delivery, there was a decrease in sample size than was originally planned, due to 10 lambs achieving ROSC with CC and PPV alone that was unanticipated. There are applicable differences in lambs when compared with humans. This being a term ovine model of cardiac arrest, the response that is observed may be different in models of bradycardia (heart rate $<60 \mathrm{bpm}$ ), preterm models and humans. Finally, although the lambs were randomised and the epinephrine dose was masked, the initial flush volume was not masked. Flush volume of $1 \mathrm{~mL}$ was used following repeated epinephrine doses which was different from the initial $3 \mathrm{~mL} / \mathrm{kg}$ in high flush groups. In clinical practice, two different flush volumes for initial and subsequent doses adds complexity. We did not evaluate $0.02 \mathrm{mg}$ $\mathrm{kg}$ dose of epinephrine. A strength of this study is its randomised and masked design closely following current guidelines. Realtime monitoring of physiological parameters were performed.

\section{CONCLUSION}

Use of $0.03 \mathrm{mg} / \mathrm{kg}$ of epinephrine followed by a $3 \mathrm{~mL} / \mathrm{kg}$ normal saline flush for the first dose of epinephrine resulted in high 
rates of ROSC (100\%) and quicker ROSC compared with use of $0.01 \mathrm{mg} / \mathrm{kg}$ of epinephrine with $1 \mathrm{~mL}$ or $3 \mathrm{~mL} / \mathrm{kg}$ of normal saline flush. Further evaluation of optimal dose of epinephrine and flush volume in a multicentre clinical trial is warranted.

Twitter Satyan Lakshminrusimha @neosatyan

Contributors DS and SL substantially contributed to the conception, design, data acquisition, analysis and interpretation, drafting the manuscript and critically revising it. PKC, SG, CK, JH, JN, BM, MR, PV, LN and DJT contributed to data acquisition, data analysis and critically revising the manuscript. All the authors approved the final version of the manuscript and agreed to be accountable for all aspects of the work.

Funding This work was supported by the American Academy of PediatricsNeonatal Resuscitation Program (SL, PC), National Institute of Health (NIH) 5 R01 HD072929 09 (SL), Children's Miracle Network Grant at UC Davis Children's Hospital (DS) and NRP research grant from Canadian Pediatric Society (DS).

Competing interests None declared.

Patient consent for publication Not required.

Ethics approval The study protocol was approved by the Institutional Animal Care and Use Committee (IACUC) at the State University of New York at Buffalo (protocol PED10085N). All experiments were performed according to animal ethical guidelines, in compliance with the ARRIVE guidelines.

Provenance and peer review Not commissioned; externally peer reviewed.

Data availability statement Data are available on reasonable request.

Supplemental material This content has been supplied by the author(s). It has not been vetted by BMJ Publishing Group Limited (BMJ) and may not have been peer-reviewed. Any opinions or recommendations discussed are solely those of the author(s) and are not endorsed by BMJ. BMJ disclaims all liability and responsibility arising from any reliance placed on the content. Where the content includes any translated material, BMJ does not warrant the accuracy and reliability of the translations (including but not limited to local regulations, clinical guidelines, terminology, drug names and drug dosages), and is not responsible for any error and/or omissions arising from translation and adaptation or otherwise.

Open access This is an open access article distributed in accordance with the Creative Commons Attribution Non Commercial (CC BY-NC 4.0) license, which permits others to distribute, remix, adapt, build upon this work non-commercially, and license their derivative works on different terms, provided the original work is properly cited, appropriate credit is given, any changes made indicated, and the use is non-commercial. See: http://creativecommons.org/licenses/by-nc/4.0/.

ORCID iDs

Deepika Sankaran http://orcid.org/0000-0002-6704-6949

Satyan Lakshminrusimha http://orcid.org/0000-0001-6098-2155

\section{REFERENCES}

1 Wyckoff MH, Weiner GM, Neonatal Life Support C. 2020 international consensus on cardiopulmonary resuscitation and emergency cardiovascular care science with treatment recommendations. Pediatrics 2020.

2 Barber CA, Wyckoff MH. Use and efficacy of endotracheal versus intravenous epinephrine during neonatal cardiopulmonary resuscitation in the delivery room. Pediatrics 2006;118:1028-34.

3 Weiner GM. Textbook of neonatal resuscitation. 7 ed. Elk Grove Village IL: American Academy of Pediatrics, 2016

4 Hayakawa K, Tasaki O, Hamasaki T, et al. Prognostic indicators and outcome prediction model for patients with return of spontaneous circulation from cardiopulmonary arrest: the Utstein Osaka project. Resuscitation 2011:82:874-80.

5 Cole JB, Knack SK, Karl ER, et al. Human Errors and Adverse Hemodynamic Events Related to "Push Dose Pressors" in the Emergency Department. J Med Toxicol 2019;15:276-86

6 Foglia EE, Langeveld R, Heimall L, et al. Incidence, characteristics, and survival following cardiopulmonary resuscitation in the quaternary neonatal intensive care unit. Resuscitation 2017;110:32-6.

7 Brune KD, Bhatt-Mehta V, Rooney DM, et al. Volume versus mass dosing of epinephrine for neonatal resuscitation: a randomized trial. Hosp Pediatr 2019:9:757-62.

8 Halling C, Sparks JE, Christie L, et al. Efficacy of intravenous and endotracheal epinephrine during neonatal cardiopulmonary resuscitation in the delivery room. J Pediatr 2017;185:232-6.

9 McNamara PJ, Engelberts D, Finelli M, et al. Vasopressin improves survival compared with epinephrine in a neonatal piglet model of asphyxial cardiac arrest. Pediatr Res 2014;75:738-48.

10 Redding JS, Pearson JW. Evaluation of drugs for cardiac resuscitation. Anesthesiology 1963:24:203-7.

11 Redding JS, Asuncion JS, Pearson JW. Effective routes of drug administration during cardiac arrest. Anesth Analg 1967;46:253-8

12 Berg RA, Otto CW, Kern KB, et al. A randomized, blinded trial of high-dose epinephrine versus standard-dose epinephrine in a swine model of pediatric asphyxial cardiac arrest. Crit Care Med 1996:24:1695-700.

13 Kilkenny C, Browne WJ, Cuthill IC, et al. Improving bioscience research reporting: the ARRIVE guidelines for reporting animal research. PLoS Biol 2010;8:e1000412.

14 Vali P, Chandrasekharan P, Rawat M, et al. Evaluation of timing and route of epinephrine in a neonatal model of asphyxial arrest. J Am Heart Assoc 2017;6. doi:10.1161/JAHA.116.004402. [Epub ahead of print: 1802 2017].

15 McKinsey S, Perlman JM. Resuscitative interventions during simulated asystole deviate from the recommended timeline. Arch Dis Child Fetal Neonatal Ed 2016;101:F244-7.

16 KPaDRA B. Model selection and Multimodel inference: a practical InformationTheoretical approach. $2 \mathrm{~d}$ ed. New York: Springer-Verlag, 2002.

17 Lawn JE, Bahl R, Bergstrom S, et al. Setting research priorities to reduce almost one million deaths from birth asphyxia by 2015. PLoS Med 2011:8:e1000389.

18 Vali P, Sankaran D, Rawat M, et al. Epinephrine in neonatal resuscitation. Children 2019:6:51.

19 Songstad NT, Klingenberg C, McGillick EV, et al. Efficacy of intravenous, endotracheal, or nasal adrenaline administration during resuscitation of near-term asphyxiated lambs. Front Pediatr 2020:8:262. 